\title{
The visual representations of a Biblical proverb and its modifications in the Internet space
}

\author{
Hrisztalina Hrisztova-Gotthardt \\ University of Pécs \\ xpucuhu@gmail.com
}

\section{Melita Aleksa Varga}

Josip Juraj Strossmayer University of Osijek

melita.aleksa@gmail.com

\section{Anna T. Litovkina}

J. Selye University

litovkin@terrasoft.hu

\section{Katalin Vargha}

Research Centre for the Humanities, Hungarian Academy of Sciences katalin.vargha@gmail.com

\begin{abstract}
Proverbs have never been considered sacrosanct; on the contrary, they have frequently been used as satirical, ironic or humorous comments on a given situation. In the last few decades, they have been perverted and parodied so extensively that their variations have been sometimes heard more often than their original forms. Naturally, the most well-known Biblical proverbs are very frequently transformed and modified in various languages. "He who digs a pit for others falls into it himself" is one of such widespread proverbs originating from the Bible. This proverb exists in almost fifty European languages, including Croatian, English, German, Hungarian and Russian. Below, we would like to demonstrate the occurrence and popularity of this proverb, as well as its transformations in the five languages. The major source for this study has been the Internet and some previously constructed Internet corpora. In the course of the present study we are going to focus primarily on the visual representation of the Biblical proverb in question and its (humorous) modifications as well on the interaction between text and image.
\end{abstract}

Keywords: proverb, anti-proverb, visual representation, interaction between (humorous) text and image 


\section{Introduction}

\subsection{Background of terminology and the most frequent types of alteration}

Proverbs have never been considered sacrosanct; on the contrary, they have frequently been used as satirical, ironic or humorous comments on a given situation. For centuries, they have provided a framework for endless transformation. In the last few decades, they have been perverted and parodied so extensively that their variations have been sometimes heard more often than their original forms. Wolfgang Mieder has coined the term Antisprichwort (antiproverb) for such deliberate proverb innovations (also known in English as alterations, mutations, parodies, transformations, variations, wisecracks, deliberate proverb innovations, or fractured proverbs) (Mieder 1983, 2006; Mieder \& Tóthné Litovkina 1999; T. Litovkina \& Mieder 2006; etc.). The form of the various anti-proverbs is never completely fixed, since antiproverbs are constantly modified to a certain extent according to the context they are used in. The term anti-proverb refers to those cases when the standard form of proverbs is consciously manipulated in order to humorously or critically confront individual proverbs (Mieder 2007: 17). It should be noted that while some anti-proverbs negate the "truth" of the original piece of wisdom completely, the vast majority of them put the proverbial wisdom only partially into question, primarily by relating it to a particular context or thought in which the traditional wording does not fit. Wolfgang Mieder's term Antisprichwort has been widely accepted by proverb scholars all over the world as a general label for such innovative alterations of and reactions to traditional proverbs: anti-proverb (English), anti(-)proverbe (French), антипословица (Russian), and anti(-)proverbium (Hungarian) (see the general discussion of the genre of anti-proverbs in T. Litovkina \& Mieder 2006: 1-54; Mieder 2007; T. Litovkina 2015; Hrisztova-Gotthardt et al. 2018a).

Although proverb transformations arise in a variety of forms, several types stand out. One of the most popular techniques of proverb alteration is punning: Matrimony is the root of all evil. (Edmund \& Workman Williams 1921: 275) \{Money is the root of all evil\}; Hair today, gone tomorrow. (Safian 1967: 42) \{Here today, gone tomorrow.

There are a number of other techniques of variation and humour devices (which are by no means mutually exclusive):

- Replacing a single word: The lack of money is the root of all evil. (Mieder et al. 1992: 416) \{The love of money is the root of all evil\}.

- The meaning of a metaphorical proverb is narrowed by putting it in a context in which it is to be interpreted literally: Marriage is a lottery! Yes, but you can't tear up your ticket if you lose! (Kilroy 1985: 421) \{Marriage is a lottery\}.

- Adding new words to the actual text of the proverb: It is more blessed to give than to receive... advice. (Berman 1997: 159) \{It is more blessed to give than to receive .

- The mixing of two (or more) proverbs (i.e., contamination, or blending): Necessity is the mother of strange bedfellows. (Berman 1997: 298) \{Necessity is the mother of invention; Politics makes strange bedfellows \}.

- The omission of (the last) word(s) of the source proverb: All's well that ends. (Kandel 1976) $\{$ All's well that ends well\}.

\subsection{The Biblical proverb $\mathrm{He}$ who digs a pit for others falls into it himself: Its familiarity and its alterations}

Typically, an anti-proverb will elicit humour only if the traditional proverb upon which it is based is also known, thus allowing the reader or listener to perceive the incongruity between the two expressions. Otherwise, the innovative strategy of communication based on the 
juxtaposition of the old and the "new" proverbs is lost. Naturally, the most well-known Biblical proverbs are very frequently transformed and modified in various languages (e.g., Mieder 2014; T. Litovkina 2018a, 2018b). One of such widely spread proverbs originating from the Bible is the proverb He who digs a pit for others falls into it himself (see Krikmann 2007: 58). Nowadays, this proverb in many languages (e.g., in Hungarian) is not related in people's minds to the Bible at all, despite the fact that it can be found in various books of the Bible at least 9 times (see T. Litovkina 2017: 189-190). The proverb He who digs a pit for others falls into it himself exists in almost fifty European languages (see Paczolay 1997: 174178), including Croatian, English, German, Hungarian and Russian languages. Below, we would like to demonstrate the occurrence and popularity of this proverb, as well as its transformations in the five languages.

According to a survey conducted by Aleksa Varga and Matovac in 2014, the Croatian proverb (Tko pod drugim jamu kopa, sam u nju upada) was in 51st place with regard to the frequency of its occurrence, out of the 105 most frequently used Croatian proverbs (Aleksa Varga \& Matovac 2015). 867 subjects from various parts of Croatia took part in the survey, and the age of respondents varied from 14 to 90. Aleksa Varga and Matovac provided questionnaires in which the first parts of proverbs were given, and the task of respondents was to complete the missing parts. On the whole, 69.67 per cent of respondents were familiar with the proverb Tko pod drugim jamu kopa, sam u nju upada; furthermore, 92.68 per cent of the respondents aged 71 or above were familiar with the proverb. This proverb is also one of the most frequently transformed proverbs in Croatian; thus, 22.25 per cent of Aleksa Varga and Matovac's respondents filled in not the original proverb but its transformation, e.g:

Ko prvi djevojci sam u nju upada. [He who comes first to the girl, falls into her himself.]

Ko rano rani, sam u nju upada. [He who wakes up early, falls into it himself.]

Tko prije preskoči jamu, sam u nju upada. [He who jumps over the pit sooner, falls into it himself.]

Despite the fact that the proverb He who digs a pit for others falls into it himself is found in the Anglo-Saxon world, it has not become a well-known proverb at all. According to the Dictionary of American Proverbs (Mieder et al. 1992: 465), it was recorded only in one US state. The proverb cannot be found in The Concise Oxford Dictionary of Proverbs (Simpson 1993). In Anna T. Litovkina's corpus of Anglo-American anti-proverbs, containing over 6,000 items, the vast majority of which have already been published (Mieder \& Tóthné Litovkina 1999; T. Litovkina \& Mieder 2006), no variations of this proverb have been found at all. This proverb is not included in the list of Anglo-American paremiological minimum, or in the list of Anglo-American paremiological optimum (Mieder 1993; Haas 2008; Fiedler 2015). It cannot be found in the Folklore Archives of the University of California at Berkeley among the 151 proverbs there, most frequently collected by Alan Dundes' students. ${ }^{1}$

Contrary to the English proverb, the German version (Wer andern eine Grube gräbt, fällt selbst hinein) is extremely popular in Germany. In the survey conducted by Peter Grzybek, the goal of which was to establish the list of the most popular German proverbs (or the paremiological minimum of the German language), all respondents filled in the second part of this proverb (Grzybek 1991: 256).

The proverb Wer anderen eine Grube gräbt, fällt selbst hinein is the fourth most frequently transformed anti-proverb in one of the collections of German anti-proverbs (Mieder 1997: 120-128), with 62 transformations provided in the collection. Let us quote here three anti-proverbs from the book:

\footnotetext{
${ }^{1}$ The list, compiled by Anna T. Litovkina, was published in Tóthné Litovkina 1998: 151-155; T. Litovkina \& Mieder 2005: 36-40.
} 
Wer andern eine Grube gräbt, kommt leicht ins Grübeln. [He who digs a pit for others starts easily pondering.]

Wer andern eine Grube gräbt, ist Bauarbeiter. [He who digs a pit for others is a construction worker.]

Wer andern eine Grube gräbt, hat viel zu tun. [He who digs a pit for others has a lot to do.]

In another collection, also by Mieder, i.e. the collection of transformations of German proverbs originated from the Bible, we find 113 humorous variations of this proverb (Mieder 2014: 184-209). It is the third most frequently transformed proverb in the book of German Biblical proverbs.

The situation is very similar in Hungary. According to two surveys conducted by Anna T. Litovkina, the proverb Aki másnak vermet ás, maga esik bele turned out to be the most wellknown Hungarian proverb. In the beginning of the 1990s, 418 respondents took part in the survey in which they got 378 beginnings of popular Hungarian proverbs, and where they had to fill in the second part. This proverb was filled in by 418 participants of the survey, i.e., by everyone (Tóthné Litovkina 1993: 126-138).

In the second half of the 1990s, Anna T. Litovkina conducted another survey in Hungary. She asked the participants of the survey to list any 10 Hungarian proverbs that came to their mind. This proverb was listed by the most respondents (69) (T. Litovkina \& Mieder 2005: 50 52). Therefore, it should not be surprising that in T. Litovkina and Vargha's corpus of over 7,000 Hungarian anti-proverbs, this proverb is the most frequently transformed proverb: over 2,000 anti-proverbs have been recorded (T. Litovkina \& Vargha 2005a, 2005b, 2006; T. Litovkina 2018a, 2018b), e.g.:

Aki másnak vermet ás, (az) (a) sírásó. [He who digs a pit for the other is a gravedigger.]

Aki másnak vermet ás, az elfárad. [He who digs a pit for the other, gets exhausted.]

The Russian equivalent of the proverb (Не рой другому яму, сам в нее попадешь) is also extremely popular. In Harry Walter and Valerij M. Mokienko's collection of Russian antiproverbs, we can find 12 transformations (Walter \& Mokienko 2005: 573), e.g.:

Не рой другому яму сам. [Do not dig a pit for another yourself]

Не рой другому яму там, где сам ходишь. [Do not dig a pit where you walk yourself]

Не рой другому яму, он ее обойдет. [Do not dig a pit for another, he will get around].

\section{Research objectives and theoretical framework}

Péter Barta, Hrisztalina Hrisztova-Gotthardt, Anna T. Litovkina, and Katalin Vargha have conducted a number of comparative studies on anti-proverbs, highlighting different aspects of proverb alterations, namely: types of variations, wordplay, language humour and topics occurring in them (for detailed analyses of techniques of alteration and humour devices most frequently employed in Anglo-American, German, French, Russian and Hungarian antiproverbs, see Barta et al. 2008, 2009; Hrisztova-Gotthardt et al. 2007, 2008; T. Litovkina et al. 2008a, 2008b; Vargha et al. 2007; Hrisztova-Gotthardt et al. 2018a). The main sources for these studies were anti-proverbs originating from personal collections, works of fiction and literature and print media. Besides, the Internet has always been considered an important source of language data (Vargha 2005; Hrisztova-Gotthardt 2006, 2007a, 2007b).

In the previous research by Barta, Hrisztova-Gotthardt, T. Litovkina, and Vargha, the coauthors have covered mainly altered texts alone. However, nowadays, with the evolution of information technologies and the enormous development of computer-mediated communication (CMC), we can observe the rapid emergence and the significance of digital visual humour within the domain of anti-proverbs as well. In the course of the present study, we are going to focus primarily on the visual representation of the well-known Biblical 
proverb He who digs a pit for others falls into it himself and its (humorous) modifications, as well on the interaction between text and image.

There are several reasons why the visualization of proverbs and anti-proverbs should be examined more closely. On the one hand, if we take a look at the proverb text itself, we can see that it is very often characterized by metaphorical phrasing and a certain image, the visualization of which can be traced back as far as the Middle Ages. One of the most wellknown and perhaps most examined visualizations of proverbs in the world is the 1559 oil-onoak-panel painting by Pieter Bruegel the Elder, Netherlandish Proverbs (see Voigt 1985; Mieder 2004), which can be regarded as the first imagery of the proverbial texts. On the other hand, the visual expression contrasted with the literal meaning of the proverb has very often been the basis of the coining of anti-proverbs. Since the second half of the 20th century, the altered proverb + image or reference to the proverb + image has been often used in advertisements, headlines or other "official" on- and offline sources (Mieder 1989, 1990; Mieder, W. \& Mieder, B. 1977; Baran 2013). Several recently published studies deal with the issue of combining traditional folkloric genres such as proverbs (in their canonical or modified form) and modern pictorial elements. Ewa Kozioł-Chrzanowska, for instance, analyses in her article (2017) the employment of well-known Polish proverbs in internet memes. Grzegorz Szpila (2017) examines the use of original and modified Polish proverbs in demotivators.

This study grew out of a paper we delivered for the fifth Hungarian Interdisciplinary Humour Conference in Piliscsaba, Hungary, in September 2017, and which was published later in Hungarian (Hrisztova-Gotthardt et al. 2018b).

In the course of the present study, we chose to focus on a single Biblical proverb, namely He who digs a pit for others falls into it himself and to examine more closely the visual representations of the proverb and its alterations in Croatian, English, German, Hungarian and Russian. All items collected from the five languages originate from the Internet and contain the proverb or its altered variant represented in a visual form and in a humorous context.

The theoretical background of our research was provided by the references both from linguistics and folklore studies, targeting the scientific examination of the digital visual humour on Internet. As a channel of communication, the Internet nowadays makes an unprocessed amount of information available to the wider audience, and the visualization of it helps the information to reach its target more efficiently. As Anneli Baran pointed out, "visualization is a very efficient tool in getting a message (be it informative, entertaining, etc.) across. It is particularly true in the Internet era when an almost new language form, the Internet language, has developed (Crystal 2001: 19). Some of its features include the blending of written and oral language" (Baran 2012: 171; cf. Veszelszki 2017a).

Marta Dynel emphasizes the importance of the use of visual elements in preserving personality when personal communication is replaced by interaction via Internet:

In the past, jokes were told primarily in face-to-face encounters among friends (and to some extent spread via published volumes). The new visual-verbal jokes reflect the evolving social role of electronic media and the fact that the Internet and mass culture seem to have replaced the former social milieu. The visual components in turn facilitate the transition from face-to-face to massmediated communication. They also play the crucial role of "creativity promoters" among Internet users.

(Dynel 2016: 685)

Apart from the decisive role of visualization, the importance of intertextuality has also been emphasized when discussing Internet communication and, in particular, Internet humour. Regarding the interrelationship between intertextuality and Internet humour, Laineste states that: 
Humor on the Internet rarely takes the form of a traditional punch-lined joke, and relies increasingly on the visual. Typical for internet humor, previous texts (including other users' comments about the humor) are often cited to create parody. Intertextuality is a common feature of this medium. Citations of known humorous texts (also parts or punch lines of jokes; see also Shmeleva \& Shmelev 2009: 225) have become popular instead of the full texts of jokes because, even though the joke form has considerably shortened since the days when the old joke tale was the prototype of folk humor, they are still too long for the purposes of online communication.

(Laineste 2016: 18)

Given the aforementioned background, we can conclude that the visual representation of antiproverbs can and should be regarded as a typical form of Internet humour, since they rely on earlier texts, cite familiar proverbs and do this all in a distorted form. However, it should be stressed that intertextuality is not just about texts. While visualizing proverbs and antiproverbs, the creators of such visualization can also use previous, well-known visual templates, treating them as references. In connection with this, it is necessary to clarify some basic concepts, namely the concept of Internet memes, macro images and demotivators.

The concept of the Internet meme (shortened meme) was derived from the original definition of the meme by Richard Dawkins $(1976)^{2}$. In the era of Internet users, the term has been used for items described as "units of popular culture that are circulated, imitated, and transformed by Internet users, creating a shared cultural experience" (Shifman 2013: 367). Furthermore, "Internet memes span various formats, for example videos, GIF files, photographs, and drawings, whether or not accompanied by text" (Dynel 2016: 662). Memes, similar to folklore, are transmitted in the course of human communication, accompanied by (partially deliberate) variation (Domokos 2014: 285). They spread faster than ever before and one of their key features is also a short life cycle.

One of the genres of Internet memes is the so-called image macro. This term describes the images that "typically consist of a picture and a witty message or a catchphrase" (http://knowyourmeme.com/memes/image-macros). We can find the category of the so-called Advice Animals within these, which are actually image macro series featuring animals of some kind (including humans) that are accompanied by captioned text to represent a character trait or an archetype that fits the role of a "stock character". (http://knowyourmeme.com/memes/advice-animals). Dynel describes this type as "canned jokes", i.e. visual-verbal jokes that are widespread and typical of the new media as a humorous form, proliferated by the creativity of individual users (Dynel 2016: 660).

Another special form occurring in the domain of visual humour is the demotivators. These are typically:

posters or pictures, usually set on a black background with a short caption and a title explaining or providing a mock-psychological or pedagogical addition to the picture. The image does not usually stand independently. It is the titles and captions that are the focus of attention and that perform as the lever that makes an ironic twist to a rather ordinary (sometimes provocative) picture.

(Laineste 2016: 19)

According to Ozga, demotivators can be defined as "intersemiotic acts as they combine two semiotic spheres - language and image" (Ozga 2014: 31). Moreover, demotivators are an exemplification of Internet humour; their (recent) aim is to draw the receivers' attention and

2 "Most definitions of Internet memes rely on a concept in evolutionary biology, coined by the English evolutionary biologist and author, Richard Dawkins. He proposed the term 'meme' (based on the Ancient Greek word mīmēma 'something imitated') to denote all non-genetic behaviour and cultural ideas that are passed on from person to person, spanning from language to the conventions of football (Davison). The concept became highly debated, and "[s]ince then, like any good meme, it has infected the culture (Dawkins)" (Börzsei 2013: 3). 
amuse them (Vinnikov 2010; Baran 2012: 176). Grzegorz Szpila identifies a specific subtype of demotivators, the so-called paremic demotivators. Paremic demotivators, as interpreted by Szpila, use proverbs (in various forms) in combination with visual elements (Szpila 2017: 306). The last section of the present study will focus on this latter subtype of demotivators.

For the scope of our research we relied on the above theoretical background. The study will, therefore, address the following research questions:

- In what way are the selected Biblical proverb and its anti-proverbs visually represented?

- How do image and text relate to each other? How do they shape, influence, and/or strengthen each other?

- How are these new text-image-unites aligned to the popular formats of digital humour?

\section{Research corpus and methodology}

\subsection{Research corpus}

Regarding the discussed notions, our research focused on the images obtained from various Internet sources with a common feature, the representation of the proverb or anti-proverb originating from the Bible, the canonical form in English being He who digs a pit for others falls into it himself. The Croatian proverb is Tko drugome jamu kopa, sam и nju upada, German Wer andern eine Grube gräbt, fällt selbst hinein, Hungarian Aki másnak vermet ás, maga esik bele, and Russian Не рой другому яму, сам в нее попадешь. The elements have been obtained using the hits of Google and Bing search engines for various keywords and word combinations, since these search engines do not index the same pages and therefore, the obtained results proved not to be the same. While searching for images, we used the strategies of entering fixed word combinations occurring in the proverbs into the search engines, taking into consideration the different variants of proverbs as well. Out of the results obtained, we filtered only the images. For instance, when searching for the images containing the German proverb, we used 'wer anderen' as a search item, and when searching for the Croatian examples we used different word combinations covering all the possible variations: "tko drugome', 'ko drugome' and '*ko drugom*'. Most of the examples were searched for and found in the summer of 2017 when we were preparing our paper for the fifth Hungarian Interdisciplinary Humour Conference in Piliscsaba (see Hrisztova-Gotthardt et al. 2018b).

For the present research, every hit submitted for further analysis had a digital image assigned to it (picture, photograph, meme-template etc.). Those examples in which a humorous text (anti-proverb) is displayed on a monochromatic or simple background without additional visual information (e.g. Figure 1 and 2) have not been included in the analysis. 


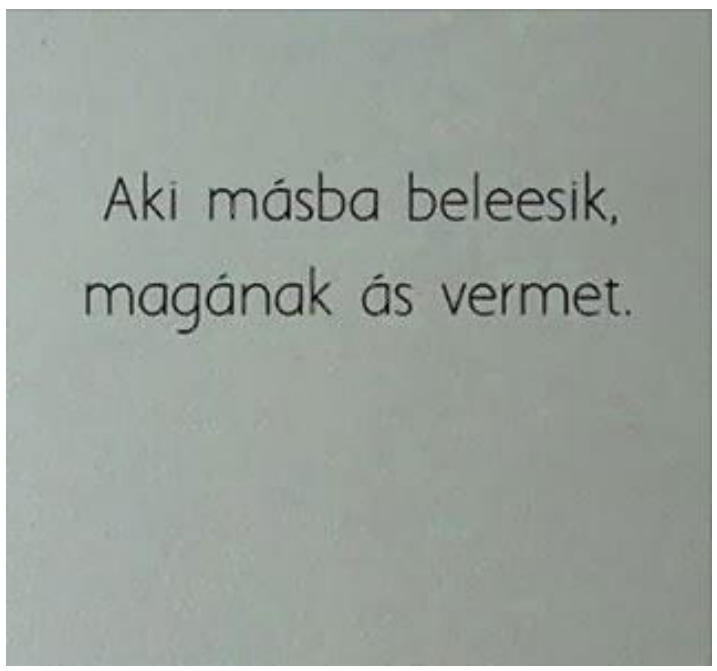

Figure 1. Hungarian: Aki másba beleesik, magának ás vermet. [He who falls for others digs a pit for himself] Source: http://qoutesandpictures.blogspot.hu/2014_03_01_archive.html, Retrieved July 24, 2017.

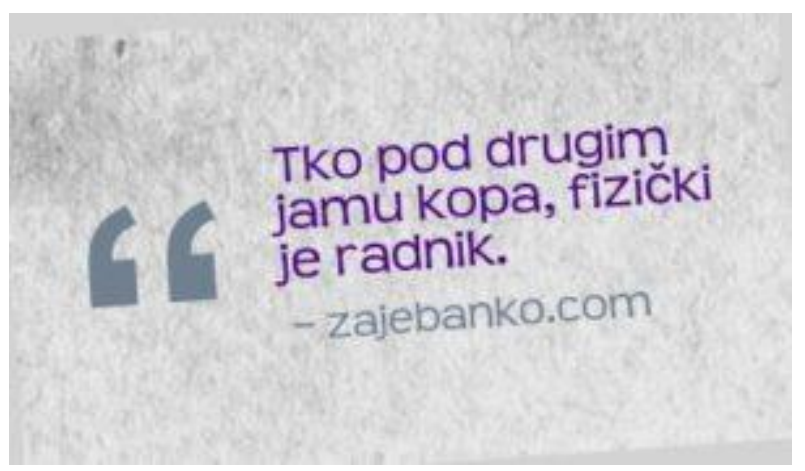

Figure 2. Croatian: Tko pod drugim jamu kopa, fizički je radnik. [He who digs a pit for other is a physical worker.] Source: http://zajebanko.com/02-smijesne-izreke-3/, Retrieved July 21, 2017.

\subsection{Research methods}

Apart from the aims mentioned in the introduction, our goal was to try to account for the similarities, or perhaps, culture-dependent features regarding the alterations of the proverbs and their digital representations. The digital items from five languages have, therefore, been systematized into one table, according to different categories based on Dynel's (2016) research. Dynel sorted the items according to the text-image relationship and the humorous/non-humorous feature into different types, explaining it as follows:

I distinguished several subtypes of image macros according to the nature of the image-caption relationship and the character of the picture (humorous or not, on its own). Albeit inspired by the relevant image, some catchphrases might exist independently and still retain their humorous potential. The humorous potential of others appears to be boosted by the anchoring images. Yet another class of memes relies heavily on both the overlaid text and the image, which are thus the sine qua non for the production of humor.

(Dynel 2016: 685)

Based on this, we came up with four categories, as displayed in Table 1. 
Table 1. Categories of visualized anti-proverbs according to the text-image relation

\begin{tabular}{|c|c|c|c|}
\hline & \multicolumn{2}{|c|}{ Image } \\
\hline & & Non-humorous & Humorous \\
\hline \multirow{2}{*}{$\stackrel{\bar{x}}{\oplus}$} & 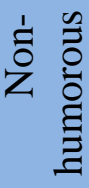 & $\begin{array}{l}\text { Non-humorous text / } \\
\text { Non-humorous image }\end{array}$ & $\begin{array}{l}\text { Non-humorous text } \\
\text { Humorous image }\end{array}$ \\
\hline & 官 & $\begin{array}{c}\text { Humorous text / } \\
\text { Non-humorous image }\end{array}$ & $\begin{array}{l}\text { Humorous text / } \\
\text { Humorous image }\end{array}$ \\
\hline
\end{tabular}

Throughout our analysis, we interpreted the humour of our examples mainly in the incongruity-resolution framework (see Dynel 2016: 672, with further references), which "tends to be regarded as compatible with verbal humor in terms of its mechanics (Hemplemann \& Samson, 2008)", referred to in Dynel 2016: 678. As Dynal points out in regard to pictures and texts, "essentially, the focal incongruities and resolution enablers can be found in the picture and text both, or in one or the other, or at the intersection of the two. Although [...] memes can be conceived as visual-verbal jokes, their humor may reside in only one component, not necessarily in both" (Dynel 2016: 678).

However, as we all know from a well-known proverb, One man's meat is another man's poison; this is very true for evaluating the humorousness of the examples discussed in the present study as well. We considered the examples cited in this paper as humorous in terms of both verbal and visual components or in terms of just one of the components. Typically, it was the incongruity (the violation of expectation) in the verbal and/or the visual element that created the humorous effect.

As mentioned above, our corpus of visualized anti-proverbs contains memes as well (demotivators and image macros) which have been analysed separately, i.e. independently of the above-mentioned categories. The reasons for this lie in the fact that, in this case, the connection of the image with the text is more significant than in other types, and the visual templates in the cases of memes make it more difficult to decide if the image is humorous or not. There is a certain background knowledge needed for understanding the templates and the associations that are connected to them.

\section{Results}

After the pre-selection, a total of 110 data were taken into the research corpus. Most examples (38) come from Russian, followed by the German and Hungarian sub-corpora with 23 and 22 data respectively. We found only 14 Croatian examples on the Internet. As we have already mentioned, among the five languages taken into consideration, this particular Biblical proverb is the least widespread in English, which is probably the reason we could find only 13 examples online.

The general analysis showed that most of the Russian examples (15) are classified as "non-humorous text/humorous image". From this, we can conclude that the visual element plays the main role in the Russian language when visualizing this proverb in a humorous manner. Germans also focus on the humorous effect induced by the image: there are seven examples of "non-humorous text/humorous image" and seven in the "demotivator" category. 
In Hungarian, demotivators seem to be the most popular with 13 examples. In nine Croatian and 10 English examples, there is a major emphasis put onto the image, placing the entries into the "non-humorous text/humorous image" category. Particularly interesting is the fact that among the Hungarian examples, there is not a single entry in which neither the image nor the text is humorous. Among the English examples, however, there are no entries found in which the text is humorous but the accompanying image itself lacks humour:

Table 2. Number of entries according to categories and languages

\begin{tabular}{|l|c|c|c|c|c|c|c|}
\hline Language & $\begin{array}{c}\text { Non- } \\
\text { humorous } \\
\text { text / } \\
\text { Humorous } \\
\text { image }\end{array}$ & $\begin{array}{c}\text { Non- } \\
\text { text / } \\
\text { Non- } \\
\text { humorous } \\
\text { image }\end{array}$ & $\begin{array}{c}\text { Humorous } \\
\text { text / Non- } \\
\text { humorous } \\
\text { image }\end{array}$ & $\begin{array}{c}\text { Humorou } \\
\text { s text / } \\
\text { Humorou } \\
\text { s image }\end{array}$ & $\begin{array}{c}\text { Memes } \\
\text { (demotivator } \\
\text { s, image } \\
\text { macros) }\end{array}$ & $\sum$ & $\%$ \\
\hline Croatian & 9 & 1 & 1 & 2 & 1 & 14 & 13 \\
\hline English & 10 & 1 & 0 & 1 & 1 & 13 & 12 \\
\hline German & 7 & 1 & 2 & 6 & 7 & 23 & 21 \\
\hline Hungarian & 6 & 0 & 2 & 1 & 13 & 22 & 20 \\
\hline Russian & 15 & 4 & 5 & 3 & 11 & 38 & 35 \\
\hline
\end{tabular}

\subsection{Analysis of the category "non-humorous text/humorous image"}

Most of the entries in our corpus belong to this category, so we can conclude that this is the most productive way of altering the proverb He who digs a pit for others falls into it himself. There are two subcategories that can be distinguished within this category. The first one contains examples where the proverb remains unchanged or only the first half is quoted, whereas the second subcategory consists of examples where the proverb is altered, but the varied text or the anti-proverb is not funny. Examining the examples, we can conclude that four percent of the images represent a machine (e.g. a grabber or a tank in our Russian examples) in an unusual situation. In a further four percent of cases, we can observe people who dig a pit or merely a pit into which people will presumably fall:

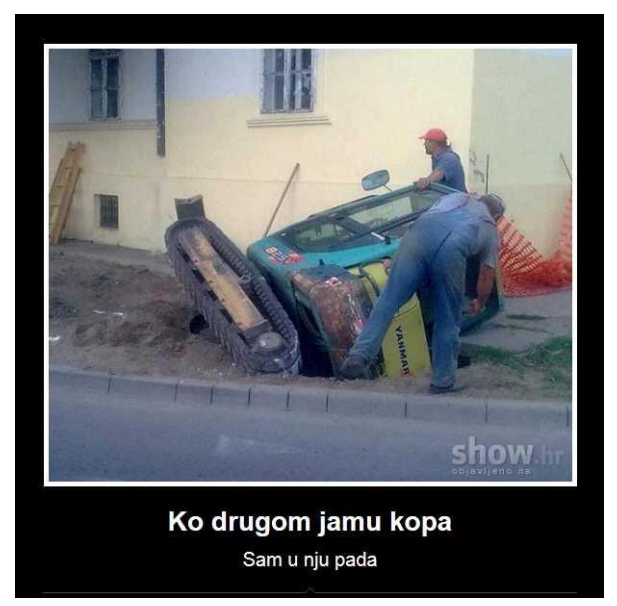

Figure 3. Croatian: Ko drugom jamu kopa sam u nju pada [He who digs a pit for others falls into it himself] Source: http://www.show.hr/poster/ko-drugom-jamu-kopa-sam-u-nju-pada/, Retrieved July 21, 2017. 


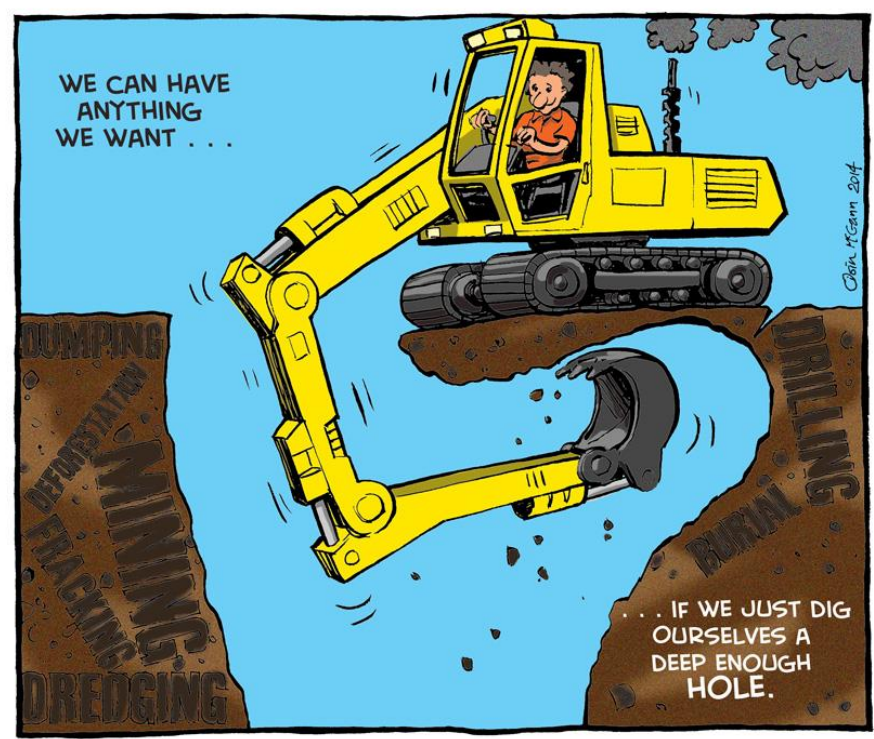

Figure 4. English: We can have anything we want... ... if we just dig ourselves a deep enough hole. Source: http://globalweatherstations.com/?cat=549, Retrieved July 21, 2017.

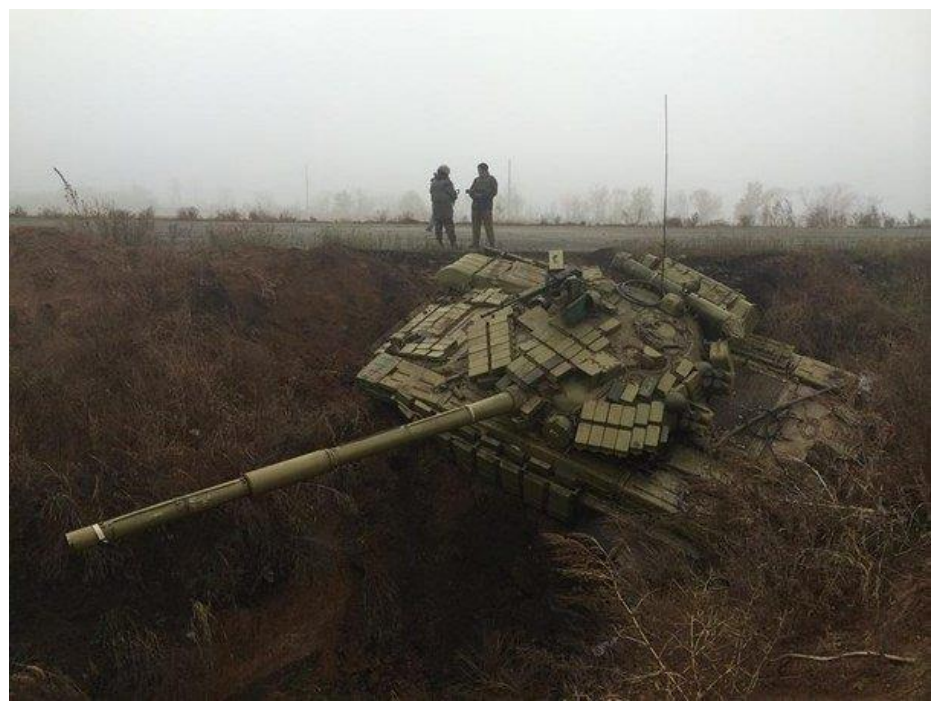

Figure 5. Russian: Не рой яму другому, сам в нее попадешь. [Do not dig a pit for another, you will fall into it yourself] Source: http://fishki.net/anti/1323431-ne-roj-jamu-drugomu-samv-nee-popadesh.html, Retrieved August 1, $2017^{3}$

${ }^{3}$ The canonical form of the proverb (Не рой яму другому, сам в нее попадешь) is the title of a newspaper article which is used in its original form at the end. The article is about two Ukrainian tanks that fall into an army pit due to Ukrainian soldiers. 


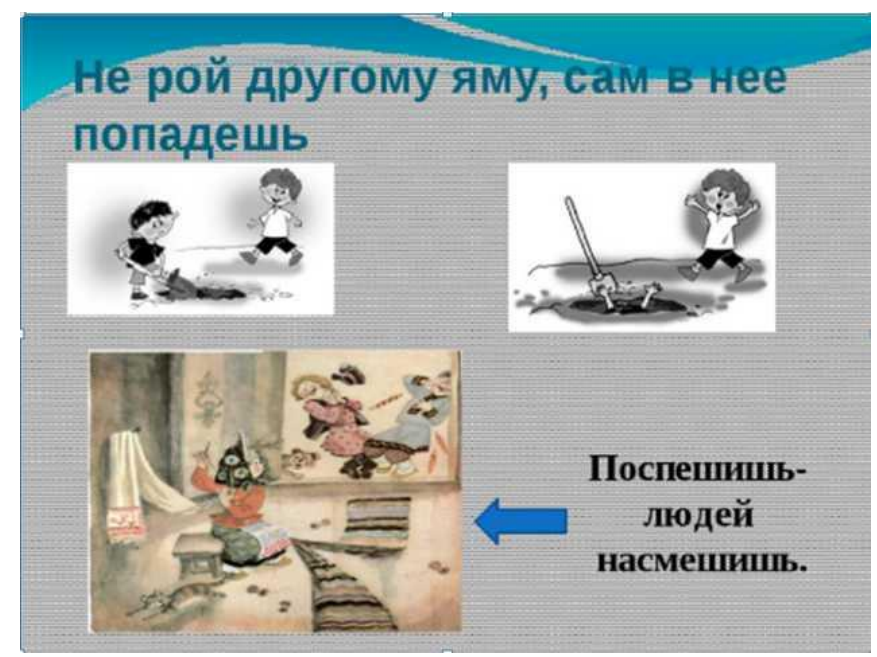

Figure 6. Russian: Не рой яму другому, сам в нее nопадешь. [Do not dig a pit for another, you will fall into it yourself] Source: http://fitnesshokolad.ru/ne-roy-yamu-drugomu-sam-vnee-popadesh/, Retrieved August 1, 2017.

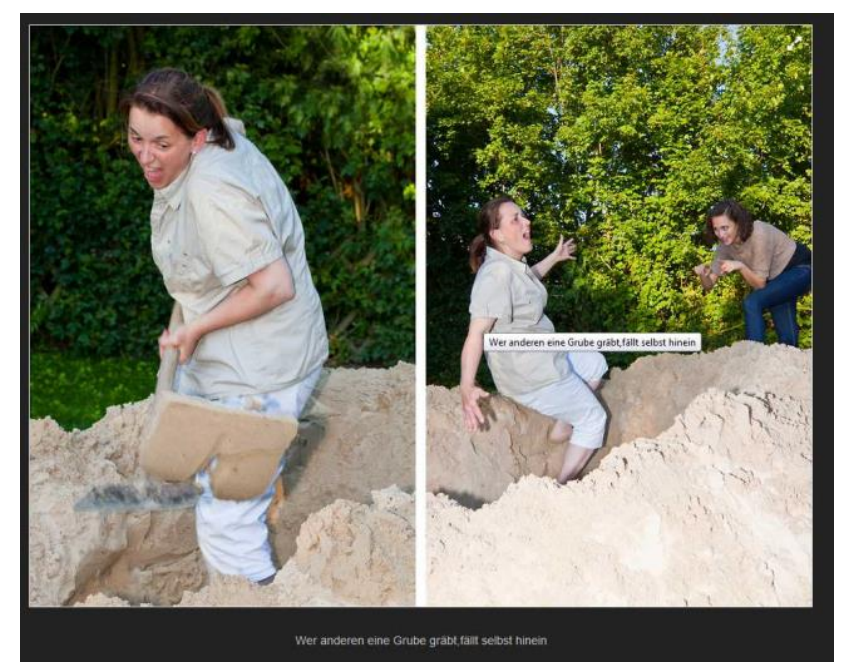

Figure 7. German: Wer anderen eine Grube gräbt, fällt selbst hinein [He who digs a pit for others falls into it himself] Source: http://www.fotocommunity.de/photo/wer-anderen-einegrube-graebtfaell-guenter-borgmann/29377549, Retrieved July 20, 2017. 


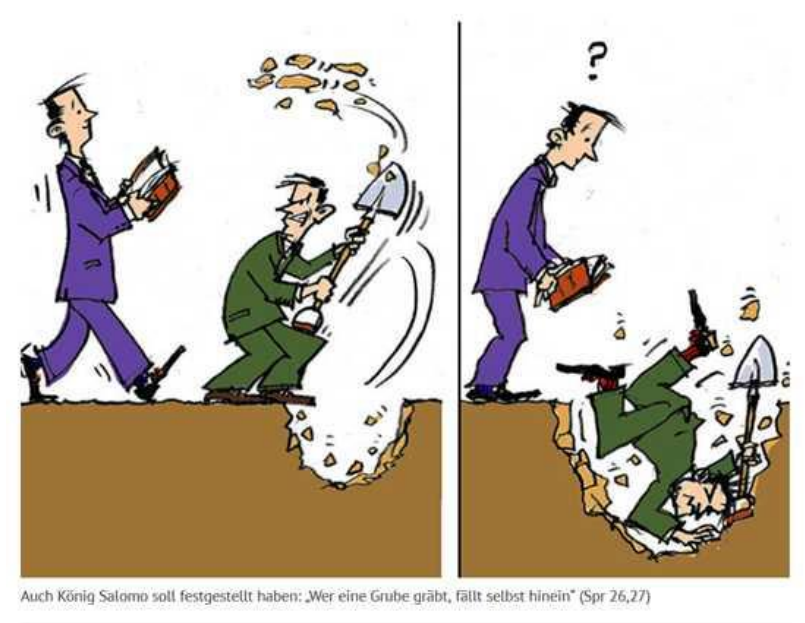

Figure 8. German Auch König Salomo soll festgestellt haben: „, Wer eine Grube gräbt, fällt selbst hinein" (Spr. 26,27). [Even King Solomon should have concluded: "He who digs a pit for others falls into it himself'] Source: https://www.erzdioezese-

wien.at/site/nachrichtenmagazin/magazin/ kleineskirchenlexikon/article/51172.html, Retrieved July 20, 2017.

There are more animals represented in the images in German and Russian examples than in the images from the other three languages. Most of the animals are cats or dogs. While the dogs dig the pit and fall into it (cf. Figure 9), the cat in the Russian example (cf. Figure 10) is not closely related to the proverb. The appearance of animals in the pictures is explained by Chandrasekaran et al. (2016: 4610), who concluded that living objects (e.g., humans or animals) contribute more to the humorous effect than non-living ones:

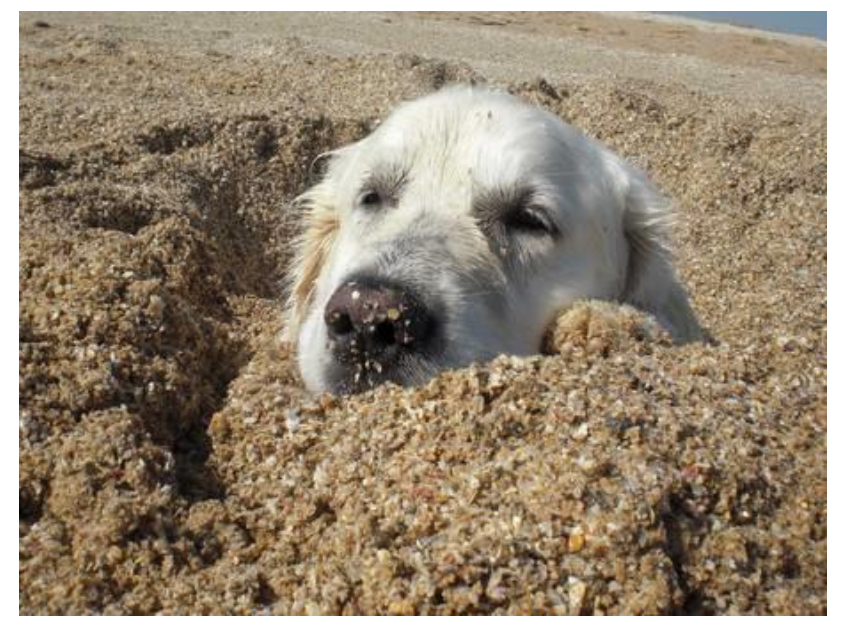

Figure 9. German: Wer andern eine Grube gräbt, fällt selbst hinein... [He who digs a pit for others falls into it himself] Source: http://anifit.tv/kategoriemenu/fotos/details/foto/werandern-eine-grube-graebt-faellt-selbst-hinein.html, Retrieved July 20, 2017. 


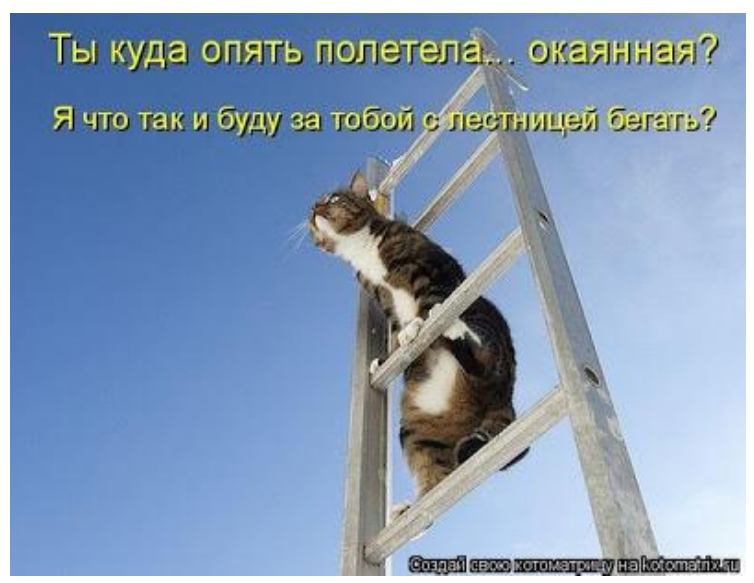

Figure 10. Russian: Не рой яму другому, сам в нее попадешь. [Do not dig a pit for another, you will fall into it yourself] Source: http://www.darchik.ru/history/1877-ne-roj-yamudrugomu-sam-v-nee-popadesh.html, Retrieved August 1, 2017.

The peculiarity of the English language examples within this category is that they mostly contain political references: most of the images depict politicians who "fall into the pit", and the texts and captions accompanying them are of political topics as well:

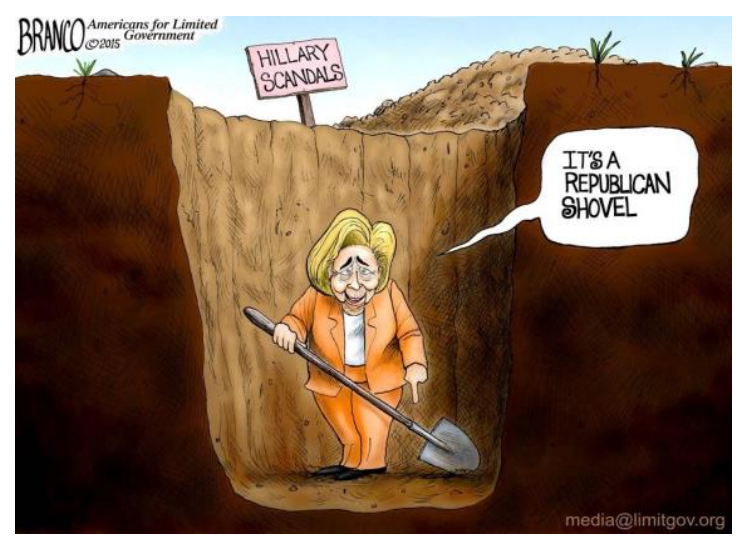

Figure 11. Hillary Scandals: It's a Republican Shovel. Source:

https://www.reddit.com/r/The_Donald/comments/56zc3c/when_all_fails_keep_digging/, Retrieved July 22, 2017.

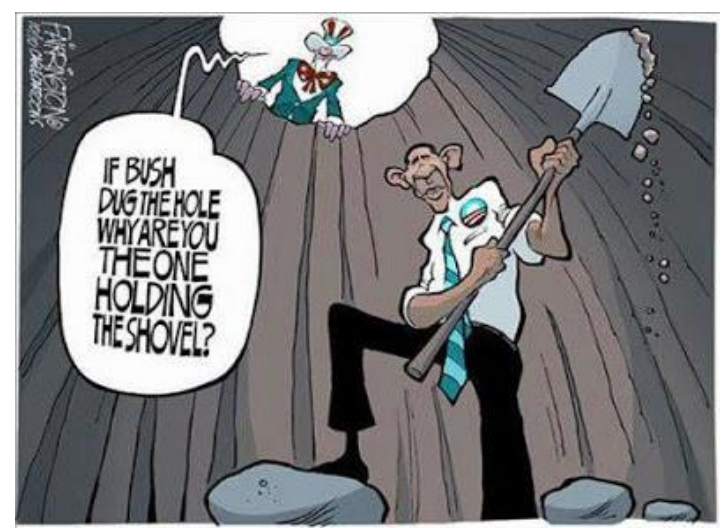

Figure 12: If Bush dug the hole why are you the one holding the shovel? Source: http://misteraow.blogspot.hr/2013/03/blaming-someone-else.html, Retrieved July 22, 2017. 


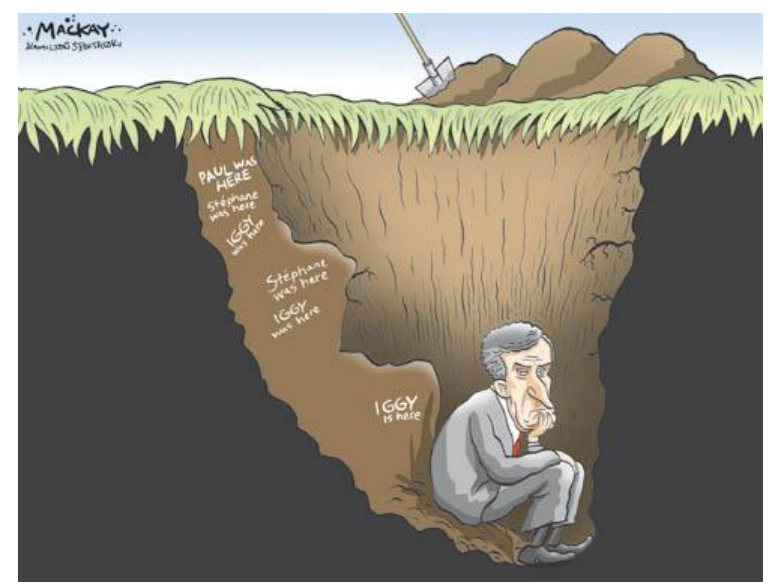

Figure 13: Paul was here... Stéphane was here ... IGGY was here... Stéphane was here ... $I G G Y$ was here... IGGY is here... Source:

https://blackstoneinitiative.com/2015/02/16/obamas-pits/, Retrieved July 21, $2017^{4}$

\subsection{Analysis of the category "non-humorous text/non-humorous image"}

Based on a general analysis of the entries in this category, we can conclude that different languages use similar images. In this regard, we fully agree with Baran (2012: 177), who states that "visual communication is more universal than verbal communication, [it is] effective across linguistic and cultural borders". Five of the entries in this category represent grabbers, pits or people with spades. For instance, in a Croatian and a German example, a traffic sign represents the person digging and just falling into the proverbial pit. These examples come from blog posts that deal with ethical issues and make reference to only the first half of the proverb. The topic of the Croatian blog is actually a conflict in the workplace where a colleague was lying and trying to make the blog author responsible for the clash; and on the German blog, a lawyer talks about buyer rights and traps on the online market Amazon.

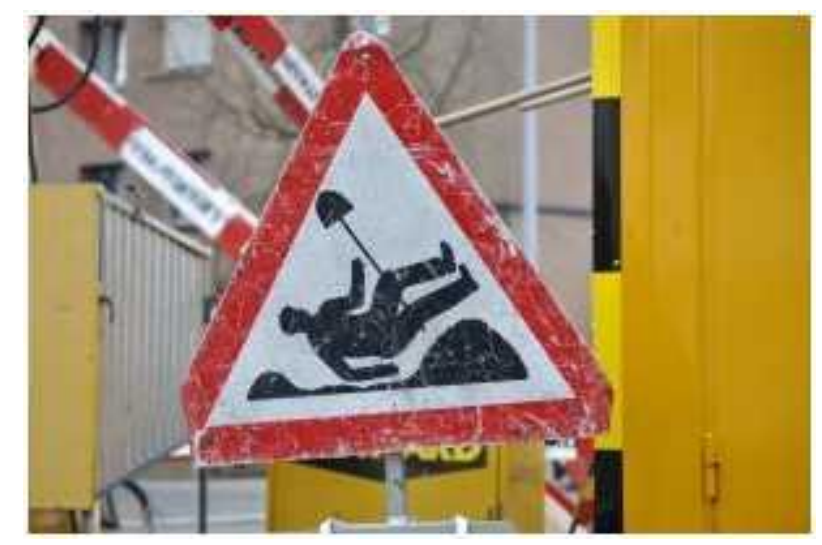

Figure 14. German: Wer anderen eine Grube gräbt... [He who digs a pit for others...] Source: http://medienrecht-blog.com/2011/06/21/nachtraeglicheaenderung_von_amazon_angebotsbeschreibungen/, Retrieved July 18, 2017.

\footnotetext{
${ }^{4}$ There is the caption "Obama's pits" above the image, and below it the following text: "As I peruse the news today, I recall to mind one immutable rule of this world".
} 


\subsection{Analysis of the category "humorous text (= anti-proverb)/humorous image"}

There are 13 items in the category "humorous text/humorous image". A major theme that occurs in the Hungarian material is relations between people, including the relationship with one's partner and mother-in-law (cf. Figure 15). The Russian material mocks the relationships between friends, neighbours and co-workers (cf. Figure 16). The Croatian material seeks to achieve a humorous effect with adultery (cf. Figure 17), and the German with food and animals (cf. Figures 18 and 19). Visual humour in this category also reflects the nature of the humour of the target native speakers of the languages examined. Similarly, we have already done research into the differences in the perception of humour in anti-proverbs by different native speakers (see Aleksa et al. 2009: 89-90) and concluded that the German native speakers do not consider anti-proverbs with the topic of sex funny, unlike the Croatian and Hungarian speakers for whom this topic is more apparent.

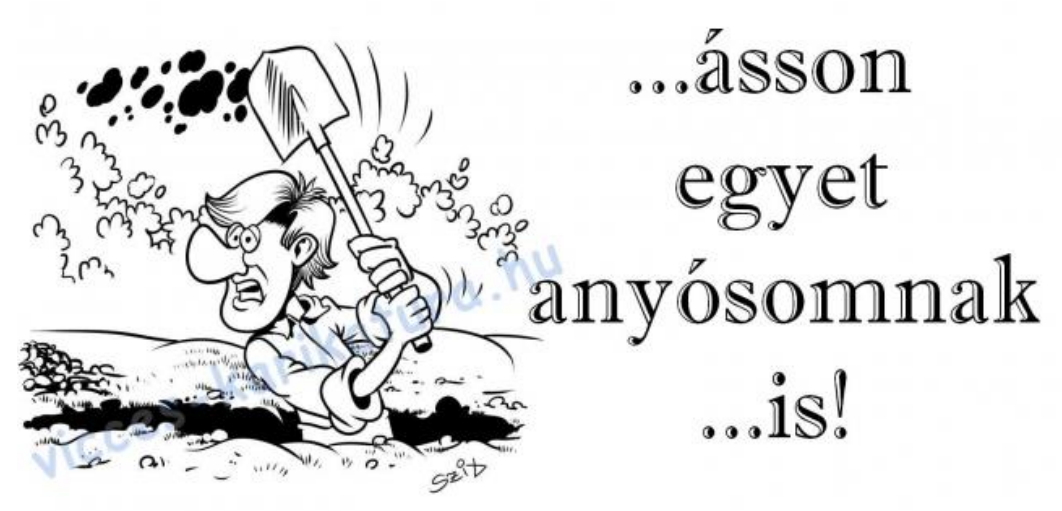

Figure 15: Hungarian: ...ásson egyet anyósomnak is! [...should dig one for my mother-inlaw as well!] Source: http://vicces-karikatura.hu/karikatura.php?id=3975, Retrieved July 7, 2017.

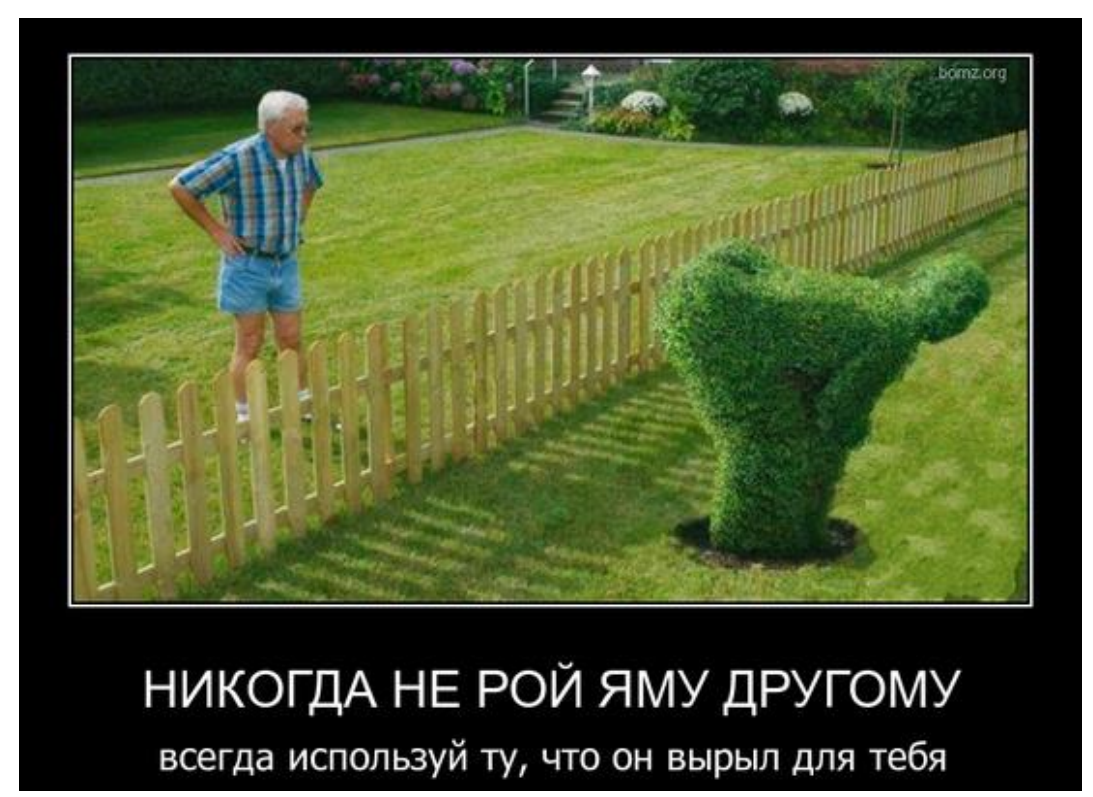

Figure 16: Russian: НИКОГДА НЕ РОЙ ЯМУ ДРУГОМУ. Всегда используй ту, что он вырылл для тебя. [Never dig a pit for another. Always use the one he has dug for you] Source: http://www.stena.ee/blog/karma-ne-zastavila-sebya-dolgo-zhdat, Retrieved April 5, 2017. 


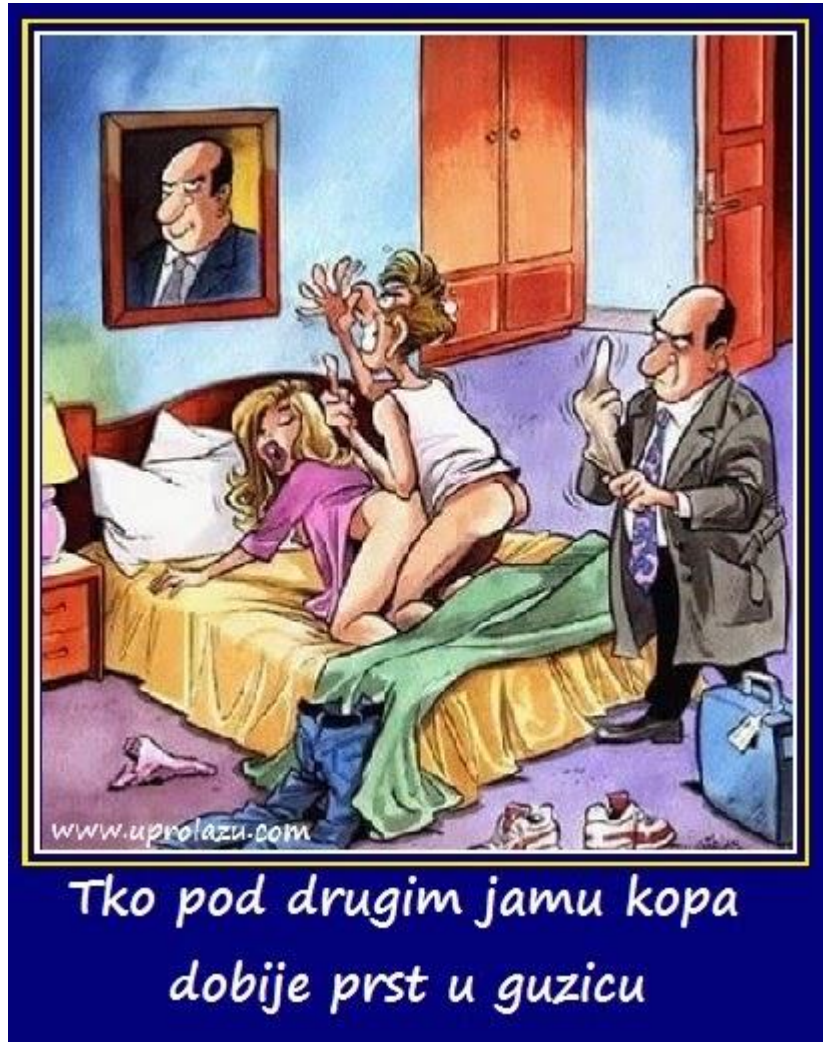

Figure 17: Croatian: Tko pod drugim jamu kopa dobije prst u guzicu [He who digs a pit for others gets a finger in his bottom]. Source: http://vicevi-zabavni.blogspot.hr/2015/05/, Retrieved July 17, 2017.

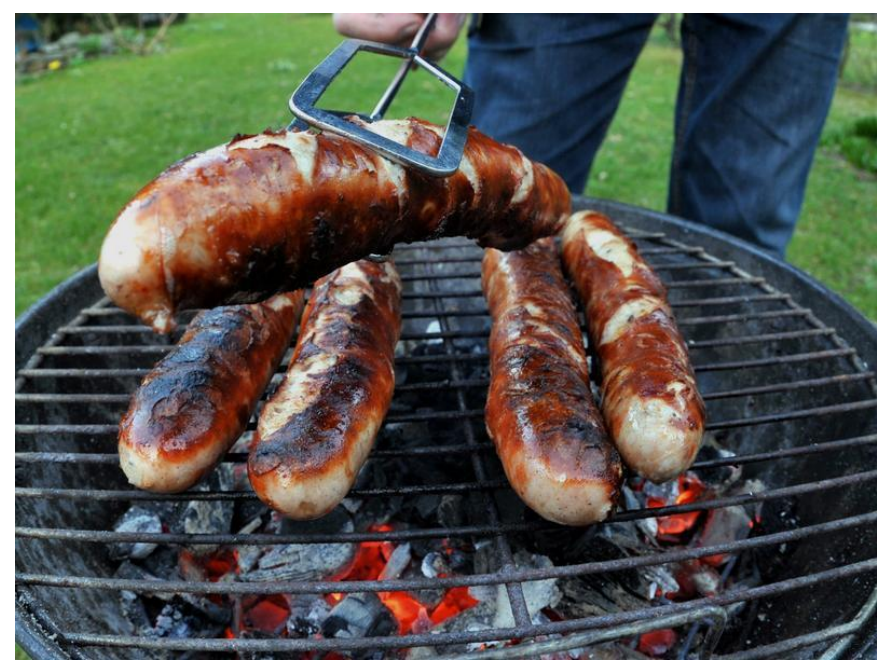

Figure 18: German: Wer andern eine Bratwurst brät, hat ein Bratwurstbratgerät! [He who fries a sausage for others has a sausage-frying-machine!] Source:

http://forum.buschtaxi.org/es-wird-zeit-eine-lang-geplante-wiederbelebung-t27869-105.html, Retrieved July 20, 2017. 


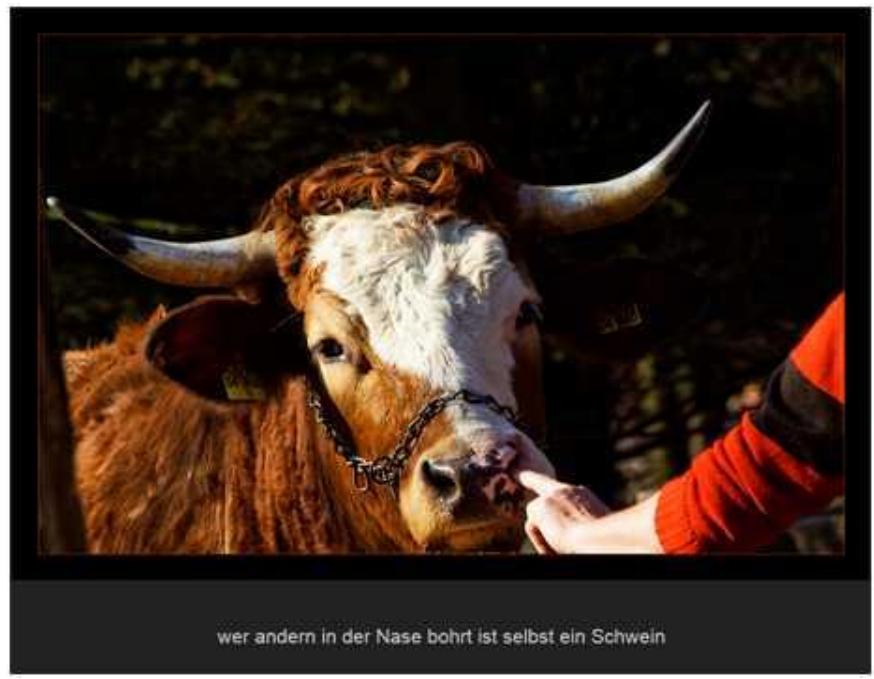

Figure 19: German: Wer andern in der Nase bohrt, ist selbst ein Schwein. [He who digs in someone else's nose, is a pig himself] Source: http://www.fotocommunity.de/photo/werandern-in-der-nase-bohrt-ist-selbst-ein-waldi-w/11990291, Retrieved July 20, 2017.

\subsection{Analysis of the category "humorous text (= anti-proverb)/non-humorous image"}

The role of the visual element in the examples in this category is to increase the humorous effect created by the anti-proverb. In the German example below (cf. Figure 20), this task is fulfilled by a traffic sign under which the following anti-proverb can be read: Wer anderen eine Grube gräbt, ist Bauarbeiter [He who digs a pit for others is a construction worker].

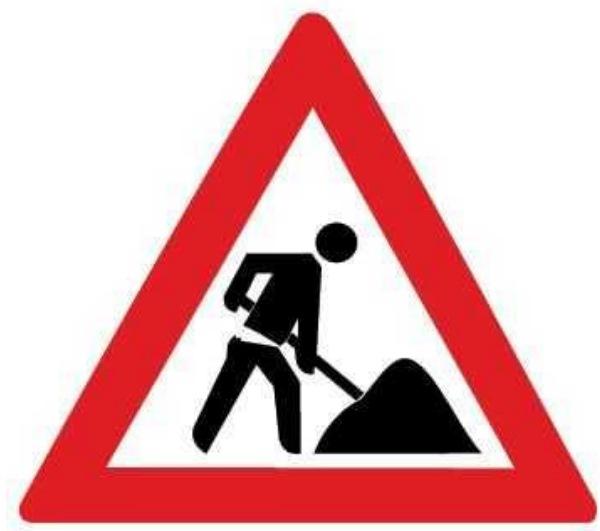

Figure 20. German: Wer anderen eine Grube gräbt, ist Bauarbeiter. [He who digs a pit for others is a construction worker] Source: http://www.szene1.at/group/grube_bauarbeiter, Retrieved July 20, 2017.

In one of our Russian examples, we have an article entitled "Рой яму - в джакузи nonademb!" [Dig a pit - you will get into the jacuzzi!] and a photograph of sand with some people digging pits (cf. Figure 21). The article talks about a beach in New Zealand called Hot Water Beach, where at tide times, an underground geothermal spring breaks up, and people dig big pits that slowly fill with hot water. Many tourists are looking for the beach to "dig up a pit" for themselves. The picture, in itself, is neutral concerning a humorous effect, but it interacts with the anti-proverb in the title of the article, and, as a result, it confirms the punchline of the twisted proverb. 


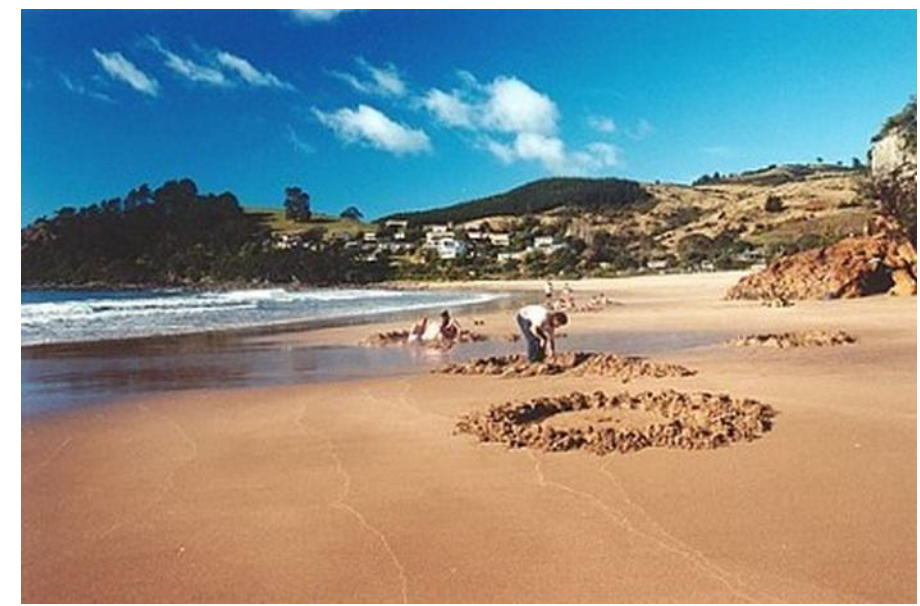

Figure 21. Russian: Рой яму - в джакузи попадешь! [Dig a pit - you will get into the jacuzzi!] Source: http://ibigdan.com/2012/04/17/roj-yamu-v-dzhakuzi-popadesh/, Retrieved April 5, 2017.

\subsection{Memes (demotivators and image macros)}

Most of the memes collected in the course of this research were obtained from Russian, Hungarian and German internet pages. The majority of the German examples are so called "image macros"; these are usually special, generated memes from the meme generator portals, by using a certain meme template. The users can then add any text they prefer, as in the trollbased meme template in Figure 22, or as in the Hungarian example by using the template of the Grumpy Cat character (cf. Figure 23):

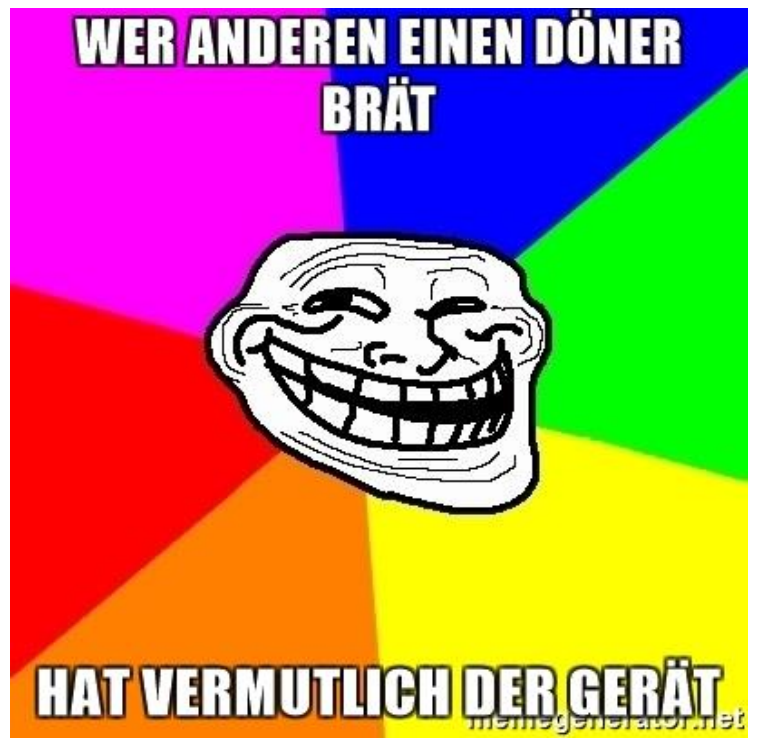

Figure 22. German: Wer anderen einen Döner brät, hat vermutlich den Gerät. [He who fries a döner for others presumably has the machine] Source:

http://es.memegenerator.net/instance/58701265, Retrieved July 20, 2017. 


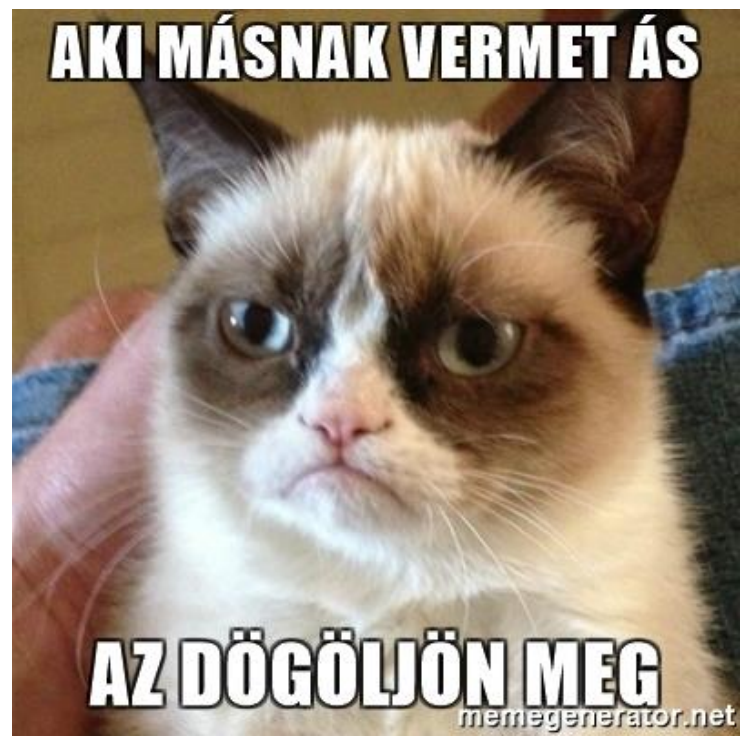

Figure 23. Hungarian: Aki másnak vermet ás, az dögöljön meg!... [He who digs a pit for others should drop dead!] Source: https://memegenerator.net/instance/32896434/grumpy-cataki-msnak-vermet-s-az-dgljn-meg, Retrieved July 24, 2017.

There is a certain background knowledge needed for the interpretation of the examples in these cases and for the perception of their humour. For understanding the first example (cf. Figure 22), one needs to be familiar with the concept and the presentation of the Internet troll, whose face has originally been derived from comics and is often used by participants in Internet communication to indicate that they themselves or their communication partner behaves like a so-called troll ${ }^{5}$. The troll in this frame of interpretation is actually "a deliberately confused, disruptive person, a provocateur in online discourse involving a lot of participants (such as an online forum or a social networking site), [...] who performs a destructive activity with different disparaging, (hateful, personal, off-topic) comments about the conversation" (Veszelszki 2017b: 19), ${ }^{6}$ which is called trolling in online communication.

The Grumpy Cat displayed in the Hungarian example (cf. Figure 23), is a popular memefigure (http://knowyourmeme.com/memes/grumpy-cat), who has been assigned, as the result of its human-like facial expression, an "anti-social" behaviour. When interpreting this type of meme, it is only with proper background knowledge that the image-text relation of this sort can be understood; that is most certainly going to be the topic of one of our future studies.

More common in the Hungarian and Russian corpus is another meme-type, the so called demotivators. When demotivators are carefully examined, we can see that there is a much stronger text-image relationship present; the background knowledge is not as necessary, as is the case with image macros, to capture their humorous effect. In the case of our anti-proverbs research, we can conclude that the photograph connected to the text is actually reinforcing the message itself, which cannot be generally concluded about all the demotivators present in the Internet sphere.

\footnotetext{
5 The interpretation of the http://knowyourmeme.com/memes/cultures/trolling meme template can be found on

${ }^{6}$ Translated by MAV.
} 


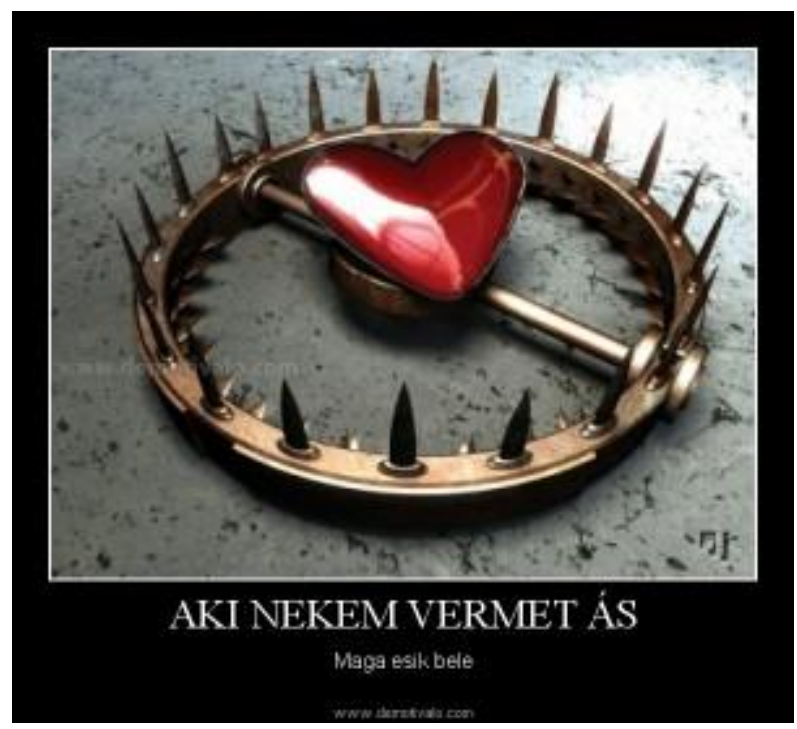

Figure 24. Hungarian: Aki nekem vermet ás maga esik bele. [He who digs a pit for me falls into it himself] Source: http://www.laosbanelomagyarok-hu.eoldal.hu/cikkek/erzesek/abaranyborbe-bujt-farkas--tanmese.html, Retrieved July 24, 2017.

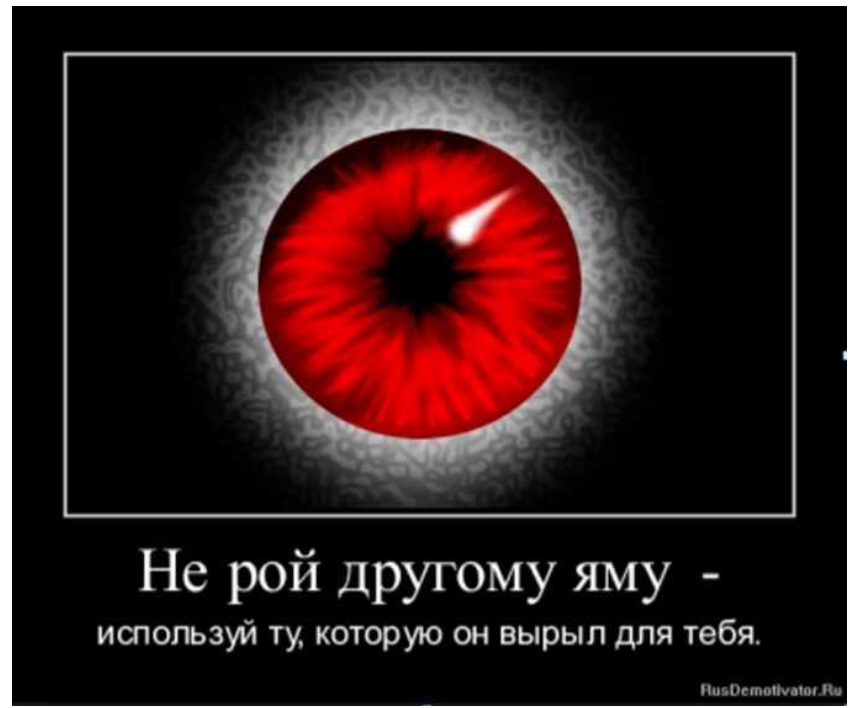

Figure 25. Russian: Не рой другому яму - используй ту, которую он вырыл для тебя. [ Dо not dig a pit for another - use the one he has dug for you] Source:

http://rusdemotivator.ru/demotivatory-polzovatelej/page/872/, Retrieved August 1, 2017.

\section{Conclusion}

Over the course of this study, we focused on the relatively new usage of proverbs and antiproverbs, namely on their visualization in the digital Internet world. The research was done on the examples of the Biblical proverb He who digs a pit for other falls into it himself and its transformations in five languages, namely Croatian, English, German, Hungarian and Russian. By examining the corpus consisting of 110 items (i.e., proverbs or anti-proverbs accompanied by images and, thus, creating a more or less humorous effect), we concluded that most examples come from Hungarian, German and Russian, where the Biblical proverb itself is one of the most frequently occurring and most frequently parodied proverbs. In languages where 
the proverb occurs less frequently (Croatian) or almost not at all (English), we found a significantly lower number of examples of digitally visualized anti-proverbs.

Upon our analysis of the items from five languages, we can draw the following conclusions regarding the visualization of the anti-proverbs:

- In most cases, a non-humorous text (the original proverb, part of it, or non-humorous transformation of the canonical proverb) and a humorous image are paired together. In these cases, the visual element enlivens the original proverb or its modification and puts it into a particular-more often than not-humorous situation.

- In our examples, digging is usually visualized with drawings and illustrations, adding a visual twist to it.

- In order to visualize the proverb or its alterations in lots of cases, photographs are used showing people, objects, machines, or vehicles in unusual situations.

- Meme templates are also used very often, which require certain background knowledge and are not always tied to a particular language or culture.

- There are also various examples, the understanding of which requires certain cultural, political, and other additional background knowledge.

To summarize, it can be stated that in the case of items from the five languages tested, the humorous effect is, indeed, the result of the interplay between the image and the text, whether or not the two elements are humorous themselves. The visual element actually helps the (entertaining) message to reach its target population more effectively.

\section{References}

Aleksa, M., Hrisztova-Gotthardt, H. \& T. Litovkina, A. (2009). 'The reception of antiproverbs in the German language area', in: Soares, R. \& Lauhagankas, O. (eds.), Actas ICP08 Proceedings. Tavira: Tipografia Tavirense, pp. 83-98.

Aleksa Varga, M. \& Matovac, D. (2015). 'Kroatische Sprichwörter im Test'. Proverbium: Yearbook of International Proverb Scholarship 33, pp. 1-28.

Baran, A. (2012). 'Visual humour on the internet', in Laineste, L., Brzozowska, D. \& Chłopicki, W. (eds.), Estonia and Poland. Creativity and Tradition in Cultural Communication. Volume 1: Jokes and Their Relations. Tartu: ELM Scholarly Press, pp. 171-186. $\quad$ Retrieved $\quad$ August $\quad 20, \quad 2017$ from http://www.folklore.ee/pubte/eraamat/eestipoola/baran.pdf

Baran, A. (2013). 'On the role of visualisation in understanding phraseologisms on the example of commercials'. Folklore 53, pp. 47-72. Retrieved August 20, 2017 from http://folklore.ee/folklore/vol53/baran.pdf

Barta, P., T. Litovkina, A., Hrisztova-Gotthardt, H. \& Vargha, K. (2008). 'Paronomázia az antiproverbiumokban - magyar, angol, német, francia és orosz példákkal', in Daczi, M., T. Litovkina, A. \& Barta, P. (eds.), Ezerarcú humor. Az I. Magyar Interdiszciplináris Humorkonferencia elöadásai. Budapest: Tinta Könyvkiadó, pp. 83-97.

Barta, P., T. Litovkina, A., Hrisztova-Gotthardt, H. \& Vargha, K. (2009). 'Antiproverbiumtanulmányok III.: Vegyülés a magyar, angol, német, francia és orosz antiproverbiumokban'. Modern Nyelvoktatás XV (1-2), pp. 41-54.

Berman, L. A. (1997). Proverb Wit \& Wisdom: A Treasury of Proverbs, Parodies, Quips, Quotes, Clichés, Catchwords, Epigrams and Aphorisms. Berkeley: A Perigee Book.

Börzsei, L. K. (2013). 'Makes a meme instead: a concise history of internet memes'. New Media Studies Magazine 7, pp. 1-28. Retrieved August 20, 2017 from http://works.bepress.com/linda_borzsei/2/

Crystal, D. (2001). Language and the Internet. Cambridge: CUP. 
Chandrasekaran, A.,Vijayakumar, A. K., Antol, S., Bansal, M., Batra, D., Zitnick, C. L. \& Parikh, D. (2016). 'We are humor beings: Understanding and predicting visual humor'. Computer Vision Foundation, Open Access Papers 2016, pp. 4603-4612. Retrieved August 20, 2017 from http://www.cvfoundation.org/openaccess/content_cvpr_2016/papers/Chandrasekaran_We_Are_Humor_ CVPR_2016_paper.pdf

Dawkins, R. (1976). The Selfish Gene. Oxford: Oxford University Press.

Domokos, M. (2014). 'Towards methodological issues in electronic folklore'. Slovensky Národopis 62 (2), pp. 283-295.

Dynel, M. (2016). "'I has seen image macros!” Advice animal memes as visual-verbal jokes'. International Journal of Communication 10, pp. 660-688. Retrieved August 20, 2017 from ijoc.org/index.php/ijoc/article/download/4101/1556

Edmund, P. \& Workman Williams, H. (1921). Toaster's Handbook: Jokes, Stories and Quotations. New York: The H. W. Wilson Company.

Fiedler, S. (2015). 'Proverbs and foreign language teaching', in Hrisztova-Gotthardt, H. \& Aleksa Varga, M. (eds.), Introduction to Paremiology. A Comprehensive Guide to Proverb Studies. Berlin: de Gruyter, pp. 294-325.

Grzybek, P. (1991). 'Sinkendes Kulturgut? Eine empirische Studie zur Bekanntheit deutscher Sprichwörter'. Wirkendes Wort. Deutsche Sprache und Literatur in Forschung und Lehre 41 (II), pp. 239-264.

Haas, H. A. (2008). 'Proverb familiarity in the United States: Cross-regional comparisons of the paremiological minimum'. The Journal of American Folklore 121 (481), pp. 319-347.

Hemplemann, C. \& Samson, A. (2008). Cartoons: Drawn jokes?, in Raskin, V. (ed.), The Primer of Humor Research. Berlin: Mouton de Gruyter, pp. 613-644.

Hrisztova-Gotthardt, H. (2006). 'Bulgarische Antisprichwörter - Ergebnisse einer Internetrecherche'. Proverbium: Yearbook of International Proverb Scholarship 23, pp. 191-210.

Hrisztova-Gotthardt, H. (2007a). 'Antiproverbiumok: a nyelvi modernizáció része', in Heltai Pál (ed.), Nyelvi modernizáció. Szaknyelv, fordítás, terminológia. XVI. Magyar Alkalmazott Nyelvészeti Kongresszus. Gödöllö, 2006. április 10-12. Pécs - Gödöllö: MANYE - Szent István Egyetem, pp. 518-523.

Hrisztova-Gotthardt, H. (2007b). 'Modifizierte bulgarische Sprichwörter im Lichte der Pragmatik: Zu den Ergebnissen einer Internetrecherche'. Acta Ethnographica Hungarica 52 (1), pp. 219-234.

Hrisztova-Gotthardt, H., Barta, P., T. Litovkina, A. \& Vargha, K. (2007). 'Antiproverbiumtanulmányok I. A bővítés és a szükítés mint ferdítési mód’. Modern Nyelvoktatás XIII (1), pp. 3-21.

Hrisztova-Gotthardt, H., T. Litovkina, A., Barta, P. \& Vargha, K. (2008). 'Poliszémia, homonímia és homofónia az antiproverbiumokban - magyar, angol, német, francia és orosz példákkal', in Daczi, M., T. Litovkina, A. \& Barta, P. (eds.), Ezerarcú humor. Az I. Magyar Interdiszciplináris Humorkonferencia elöadásai. Budapest: Tinta Könyvkiadó, pp. 98-108.

Hrisztova-Gotthardt, H., T. Litovkina, A., Barta, P. \& Vargha, K. (2018a). A közmondásferditések ma: Öt nyelv antiproverbiumainak nyelvészeti vizsgálata. Budapest: Tinta Könyvkiadó.

Hrisztova-Gotthardt, H., T. Litovkina, A., Vargha, K., Aleksa Varga, M. \& Keglević, A. (2018b). 'Aki másnak vermet ás... Egy bibliai közmondás elferdített változatai és vizuális ábrázolása az interneten', in Nemesi, A. L., T. Litovkina, A., Barta, Zs. \& Barta, P. (eds.), Humorstílusok és -stratégiák. Budapest: Tinta Könyvkiadó, pp. 262-286. 
Kandel, H. (1976). The Power of Positive Pessimism: Proverbs for Our Time. Los Angeles: Price/Stern/Sloan Publisher.

Kilroy, R. (1985). Graffiti: The Scrawl of the Wild and Other Tales from the Wall. London: Corgi Books.

Kozioł-Chrzanowska, E. (2017). 'Well-known Polish proverbs in internet memes'. Proverbium. Yearbook of International Proverb Scholarship 34, pp. 179-217.

Krikmann, A. (2007). 'Digging one's own grave'. Folklore: Electronic Journal of Folklore 35, pp. 53-60.

Laineste, L. (2016). 'From joke tales to demotivators: A diachronic look at humorous discourse in folklore'. Traditiones 45 (3), pp. 7-25. Retrieved August 20, 2017 from https://ojs.zrc-sazu.si/traditiones/article/view/4825

T. Litovkina, A. (2015). 'Anti-proverbs', in Hrisztova-Gotthardt, H. \& Aleksa Varga, M. (eds.): Introduction to Paremiology: A Comprehensive Guide to Proverb Studies. Berlin: de Gruyter, pp. 326-352.

T. Litovkina, A. (2017). Aki keres, az talál. Bibliai közmondások szótára. Budapest: Tinta Könyvkiadó.

T. Litovkina, A. (2018a). “„Aki keres, az talál? Talál a halál!” - Bibliai proverbiumok ferdítései', in Nemesi, A. L., T. Litovkina, A., Barta, Zs. \& Barta Péter (eds.), Humorstílusok és -stratégiák. Budapest: Tinta Könyvkiadó, pp. 209-239.

T. Litovkina, A. (2018b). “„Aki másnak vermet ás, az talán a Messiás?” A legnépszerübb bibliai közmondás ferdítései', in Nemesi, A. L., T. Litovkina, A., Barta, Zs. \& Barta Péter (eds.), Humorstílusok és -stratégiák. Budapest: Tinta Könyvkiadó, pp. 240-261.

T. Litovkina, A. \& Mieder, W. (2005). „A közmondást nem hiába mondják”. Vizsgálatok a proverbiumok természtéről és használatáról. Budapest: Tinta Könyvkiadó.

T. Litovkina, A. \& Mieder, W. (2006). Old Proverbs Never Die, They Just Diversify: A Collection of Anti-proverbs. Burlington - Veszprém: The University of Vermont - The Pannonian University of Veszprém.

T. Litovkina, A. \& Vargha, K. (2005a). „Éhes diák pakkal álmodik”. Egyetemisták közmondás-elváltoztatásai. Budapest: Private publication.

T. Litovkina, A. \& Vargha, K. (2005b). „Viccében él a nemzet”. Magyar közmondásparódiák. Budapest: Private publication.

T. Litovkina, A. \& Vargha, K. (2006). „Viccében él a nemzet”. Válogatott közmondásparódiák. Budapest: Nyitott Könyvmühely.

T. Litovkina, A., Barta, P., Hrisztova-Gotthardt, H. \& Vargha, K. (2008a). 'A szójáték egyes típusai az antiproverbiumokban - magyar, angol, német, francia és orosz példákkal', in Daczi, M., T. Litovkina, A. \& Barta, P. (eds.), Ezerarcú humor. Az I. Magyar Interdiszciplináris Humorkonferencia elöadásai. Budapest: Tinta Könyvkiadó, pp. 109122.

T. Litovkina, A.,Vargha, K., Barta, P. \& Hrisztova-Gotthardt, H. (2008b). 'Punning in AngloAmerican, German, French, Russian and Hungarian anti-proverbs'. Proverbium. Yearbook of International Proverb Scholarship 25, pp. 249-288.

Mieder, W. (1983). Antisprichwörter. Band I. Wiesbaden: Verlag für deutsche Sprache.

Mieder, W. (1989). American Proverbs: A Study of Texts and Contexts. Bern: Peter Lang.

Mieder, W. (1990). 'A picture is worth a thousand words: From advertising slogan to American proverb'. Southern Folklore 47, pp. 207-225.

Mieder, W. (1993). "Proverbs everyone ought to know". Paremiological minimum and cultural literacy', in Mieder, W., Proverbs Are Never out of Season. Popular Wisdom in the Modern Age. New York, Oxford: Oxford University Press, pp. 41-57.

Mieder, W. (1997). Ver-kehrte Worte: Antizitate aus Literatur und Medien. Wiesbaden: Quelle \& Meyer. 
Mieder, W. (2004). (ed.) The Netherlandish Proverbs: An International Symposium on the Pieter Brueg(h)els. Burlington: University of Vermont Press.

Mieder, W. (2006). “Andere Zeiten, andere Lehren”. Sprichwörter zwischen Tradition und Innovation. Baltmannsweiler: Schneider Verlag Hohengehren.

Mieder, W. (2007). 'Anti-proverbs and mass communication: The interplay of traditional and innovative folklore'. Acta Ethnographica Hungarica 52 (1), pp. 17-46.

Mieder, W. (2014). "Wer andern eine Grube gräbt ..." - Sprichwörtliches aus der Bibel in moderner Literatur, Medien und Karikaturen. Wien: Praesens.

Mieder, W. \& Mieder, B. (1977). 'Tradition and innovation: Proverbs in advertising'. Journal of Popular Culture 11, pp. 308-319.

Mieder, W. \& Tóthné Litovkina, A. (1999). Twisted Wisdom: Modern Anti-Proverbs. Burlington: University of Vermont.

Mieder, W. (editor-in-chief), Kingsbury, S. A. \& Harder, K. B. (eds.) (1992). A Dictionary of American Proverbs. New York: Oxford University Press.

Norrick, N. (1989). 'Intertextuality in humor'. Humour: International Journal of Humour Research 2 (2), pp. 117-139.

Ozga, K. (2014). 'Demotivators as deprecating and phatic multimodal communicative acts', in Maiorani, A. \& Christie, C. (eds.), Multimodal Epistemologies: Towards an Integrated Framework. London: Routledge, pp. 28-49.

Paczolay, Gy. (1997). European Proverbs in 55 Languages With Equivalents in Arabic, Persian, Sanskrit, Chinese and Japanese. Veszprém: Veszprémi Nyomda.

Safian, L. A. (1967). The Book of Updated Proverbs. New York: Abelard-Schuman.

Shifman, L. (2013). 'Memes in a digital world: Reconciling with a conceptual troublemaker'. Journal of Computer-Mediated Communication 18, pp. 362-377. Retrieved August 20, 2017 from http://onlinelibrary.wiley.com/doi/10.1111/jcc4.12013/epdf

Shmeleva, E. \& Shmelev, A. (2009). 'Contemporary Russian jokes: A new cast of characters', in Krikmann, A. \& Laineste, L. (eds.), Permitted Laughter: Socialist, Post-Socialist and Never-Socialist Humor. Tartu: ELM Scholarly Press, pp. 225-236.

Simpson, J. (1993). The Concise Oxford Dictionary of Proverbs. Oxford: Oxford University Press.

Szpila, G. (2017). 'Polish paremic demotivators: tradition in an internet genre'. Journal of American Folklore 130 (517), pp. 305-334.

Tóthné Litovkina, A. (1993). Felmérés a magyar közmondások ismeretére vonatkozóan és a felmérésben legismertebbeknek bizonyult közmondások elemzése. Kandidátusi disszertáció.

Tóthné Litovkina, A. (1998). 'An analysis of popular American proverbs and their use in language teaching', in Heissig, W. \& Schott, R. (eds.), Die heutige Bedeutung oraler Traditionen - Ihre Archivierung, Publikation und Index-Erschließung (The Present-Day Importance of Oral Traditions: Their Preservation, Publication and Indexing). Opladen Wiesbaden: Westdeutscher Verlag, pp. 131-158.

Vargha, K. (2005). 'Nincs új a net alatt. Antiproverbiumok az interneten', in Gulyás, J. \& Tóth, A. (eds.), Mindenes Gyüjtemény II. Tanulmányok Küllős Imola 60. születésnapjára. (Artes Populares 22.) Budapest: ELTE Folklore Tanszék, pp. 371-388.

Vargha, K., T. Litovkina, A., Barta, P. \& Hrisztova-Gotthardt, H. (2007). 'A csere mint az antiproverbiumok ferdítési módja - magyar, angol, német, francia és orosz példákkal'. Modern Nyelvoktatás XIII (2-3), pp. 23-42.

Veszelszki Ágnes (2017a). Digilect. The Impact of Infocommunication Technology on Language. Berlin: de Gruyter. 
Veszelszki, Á. (2017b). 'Verbális és vizuális agresszió online: az internetes trollok'. Jel-Kép 2017 (2), pp. 17-29. Retrieved August 20, 2017 from http://communicatio.hu/jelkep/2017/2/JelKep_2017_2_Veszelszki_Agnes.pdf

Vinnikov, V. (2010). Демотиваторы. Жанр русского фольклора. Retrieved February 26, 2020 from http://www.zavtra.ru/content/view/2010-11-1081.

Voigt, V. (1985). 'Németalföldi közmondások id. Pieter Bruegel festményén. Magyar történeti folklorisztikai elemzéskísérlet'. Ethnographia XCVI (1), pp. 50-71.

[Walter] Вальтер, Х. \& Мокиенко, В. М. (2005). Антипословицы русского народа. СанктПетербург: Нева. 